\title{
A kollagén szerepe és hatása az emberi szervezetre
}

\section{The role and effect of collagen on the human body}

Szerzo"/Author/Rovatvezető: DR. HABIL. FRITZ PÉTER egyetemi docens PETER FRITZ DR. HABIL. associate professor Ferencvárosi Torna Club, Miskolci Egyetem pfritz@hotmail.hu Tudományos tevékenysége: doktori iskolában témavezető Scientific activity: supervisor in doctoral school

Főbb kutatási terület: sporttáplálkozás, rekreáció Main areas of research: sports nutrition, recreation
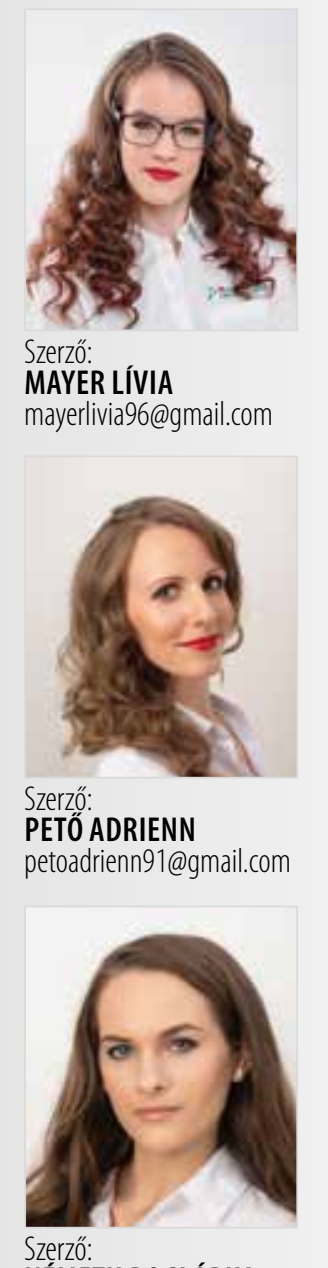

NÉMETH BOGLÁRKA

Munkahely: Superfoods PTE-Táplálkozástudományi MSc ME-Rekreáció MSc nemethboglarka94@gmail.com

\section{ÖSSZEFOGLALÁS:}

A kollagén is fehérje, így építőkövei az aminosavak. Szervezetünk képes előállítani, amennyiben az étkezésünk során kielégítő mennyiségben jutunk fehérjegazdag táplálékhoz. Szintéziséhez azonban nélkülözhetetlen a C-vitamin, mely segíti a kollagénképző aminosavak kapcsolódását. 28 ismert kollagéntípus van, azonban a szervezet kollagénjének közel 90\%-a az I. típus családjába tartozik. A kollagént sertésből, marhából, csirkéből és különböző tengeri állatokból lehet kinyerni. Mivel szervezetünk nagy mennyiségben tartalmazza, fogyasztása hatással van a bőrre, szemre, hajra, körömre, inakra, szalagokra, izmokra, porcokra, csontokra, az emésztésre és szívünk egészségére is. Évek óta növekvő tendenciát mutat a kereslet a kollagént tartalmazó étrend-kiegészítók iránt. A kollagénpiac - ezen belül is a hidrolizált kollagén - további növekedését várják.

Kulcsszavak: kollagén, hidrolizált kollagén, étrend-kiegészítés, zselatin, élettani hatás

\section{ABSTRACT:}

Collagen is also protein, its building blocks are the amino acids. Our body can produce them if we eat enough protein-rich food. However, vitamin C is essential for synthesis, it helps bind collagen-forming amino acids. There are 28 known types of collagens, but $90 \%$ of our body's collagens are in the 1st type. Porks, beefs, chickens and different types of sea animals contain collagen. Collagens are in our body in large quantities, that's why its comsumption affects our skin, eyes, hair, nails, tendons, ligaments, muscles, cartilage, bones, digestion, and the health of our hearts as well. The demand for collagen-containing dietary supplements has been on an increasing trend for years. This market, including hydrolysed collagen, is expected to grow further.

Keywords: collagen, hydrolysed collagen, dietary supplement, gelatine, physiological effect

\section{Mi az a kollagén-collagen?}

Az emlősökben található leggyakoribb fehérjékről van szó (teljes fehérjetömeg 30\%-a). A kollagéncsalád 28 elemből áll. Strukturális szerepük van, amelyek a szöveteink mechanikai, alaki és szerveződési tulajdonságaihoz járulnak hozzá ( $R i$ card - Blum, 2011).

Az emberi szervezetben az összes fehérje egyharmada, valamint a bőr száraz tömegének háromnegyede kollagén. Az extracelluláris mátrix (ECM) legelterjedtebb alkotóeleme (Shoulders Raines, 2009).

A kollagén fehérje híján van egy alapvető aminosavnak, a triptofánnak, valamint alacsony a cisztein és metionin tartalma, ezért nem számít teljes értékű proteinforrásnak, vagyis inkomplett protein (Paul et al. 2019). Inkomplett proteinről akkor beszélünk, ha a fehérjében nem található meg minden esszenciális aminosav.
Funkcionális ételként viszont tekinthetünk rá, ugyanis fiziológiailag aktív peptidek és aminosavak forrása. Képes az egészség optimalizálására és kielégíti a fokozott igényeket, melyeket az öregedés és testmozgás vált ki (Paul et al. 2019).

\section{A kollagén felépítése:}

A kollagén hármas hélixszerkezetéről ismert fehérjecsoportra utal. A korábban említett 28 típusú kollagén közül létezik olyan, mely három azonos láncból áll, például a porcban, ez a II-es típusú kollagén. De vannak olyan láncokból állók is, melyek genetikailag elkülönülnek, például a bőrben és csontban előforduló kollagén, ez az I-es típusú kollagén.

A hármas hélix csavarodása miatt a lehető legkisebb mellékcsoporttal rendelkező aminosav fér el legjobban a szerkezetben, ami a glicin. Szinte minden harmadik tagját ez az aminosav képezi (Christov, 2016). 


\section{A kollagén fóbb típusaï}

I-es típus: a leggyakrabban előforduló kollagéntípus. Megtalálható a kötőszövetekben, beleértve az ínt, ínszalagot, a dermist és az ereket. Az ECM szakítószilárdságának fó alkotóeleme és elsődleges meghatározója. Prokollagénként szintetizálódik. Legfőbb forrásai a tengeri halak, valamint kisebb mennyiségben a sertésekben is megtalálható (León-López et al. 2019).

II-es típus: felnőtteknél az ízületi felületek hialinporcának fő szerkezeti alkotóeleme, ezzel befolyásolja az ízületek múködését. Ezenkívül megtalálható más szövetekben is, mint az intervertebrális porckorong sejtmagja, a retina, sclera és a szemlencse. Táplálékkiegészítőként az ízületi fájdalmak és gyulladások kezelésére alkalmazzák, valamint étrendi fehérjeforrásként is (Line - Rhodes - Yamada, 1993).

III-as típus: a szövetekben a második leggyakrabban előforduló kollagéntípus. Általában azokban a szövetekben található meg, amelyek rugalmas tulajdonsággal rendelkeznek, mint a bőr, a tüdő, a bélfalak és az erek fala. Ezenkívül megtalálható a csontban, porcban, dentinben, inakban és más kötőszövetekben található rostos fehérjékben is. Három alfa-1 láncból álló homotrimer, amely felépítésében és múködésében hasonlít más fibrilláris kollagénekre. Prokollagénként szintetizálódik, hasonlóan az I-es típusú kollagénhez, de az N-terminális propeptid kötődve marad az érett III fibrilláris formában. Legfőbb forrásai a sertések és marhák (León-López et al. 2019).

\section{Kollagén természetes forrásai}

Marha: A szarvasmarhák csontja az egyik fő mellékterméke a szarvasmarha-feldolgozó iparnak, ezért széles körben használják fel jó minőségű kollagén előállítására. Fogyasztása növeli a szervezetben az I-es és III-as típusú kollagén mennyiségét. Így csökkentheti a ráncokat, rugalmasabbá teheti a bőrt, és növelheti annak nedvességtartalmát (Song et al. 2017).

Sertés: Tipikusan a sertés csontjából és bőréből nyerik ki. I-es és III-as típusú kollagént tartalmaz, így pozitív hatással lehet a bőr rugalmasságára, nedvességtartalmára és a látható ráncok csökkentésére (Tung et al. 1985).

Csirke: A szárnyasokból származó kollagént (II-es típus) ízületi, háti, és nyaki fájdalmak kezelésére alkalmazzák. Kondroitint és glükozamint tartalmaz, amelyek szerepet játszanak a porcok regenerálódásában (Bakilan et al. 2016).

Tengeri: a tengeri halakból származó kollagén felhasználása egyre nagyobb teret kap az étrend-kiegészítők piacán. Jelentős mennyiségü haltömeg kerül kidobásra bőr, csont, uszony, fej, bél és pikkely formájában. Ezekből a maradványokból kollagént lehet kinyerni, ami a környezetvédelem szempontjából is előnyös. Tipikusan az I-es típusú kollagént nyerik ki a bőrből, inakból, csontból és izomból, amely a leggyakoribb kollagéntípus. Ezenkívül a II-es típusú kollagént is ki lehet nyerni a halak porcából (Silva et al. 2014).

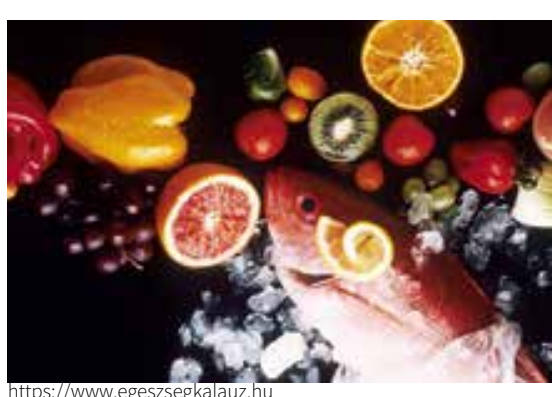

\section{Emlős vs halból nyert kollagén:}

Az elmúlt időszakban felfedezték, hogy kockázatos lehet az emlősök szöveteiből nyert kollagénfehérjék felhasználása a bennük lévő kórokozók miatt, mivel nagy kihívást jelent ezen fehérjék megtisztítása, és hatékony eszközökre van szükség annak érdekében, hogy elkerüljük a fehérje szerkezetének megváltozását. A nehéz előállítás és magas költségek csökkentik az igényt az emlősökből nyert kollagén termelésére, ellentétben a halakból nyert kollagénére. A halakból nyert kollagént biztonságos és olcsó előállítani, megtartja a tisztaságát, térszerkezetét, biokompatibilitását és magas hőstabilitását, viszont könnyen denaturálódik (Sripriya - Kumar, 2015).

Az MCP-k (marine collagen peptide = halkollagén) bevitelének biztonságával kapcsolatos legnagyobb aggodalom a kollagénszintézishez köthető oxidatív stressz fokozott kockázata, valamint az MCP-k által stimulált fagociták ROS-termelése (reaktívoxigén-származékok). De Luca és munkatársaik 2016-ban publikált kutatásában az MCP-ket növényi eredetű bőrre ható antioxidánsokkal kombinálva (Q1O, szőlőmagkivonat, luteolin, szelén) fogyasztották az alanyok. Jelentősen javult a bőrük rugalmassága, faggyútermelése és a dermális ultrahangos markerek. A metabolikus adatok a plazma hidroxi-prolin és ATP (adenozin-trifoszfát, kémiai energiát szállít sejten belül) tárolásának jelentős növekedését mutatták az eritrocitákban. A redox paraméterek, a GSH (redukált glutation) / koenzim Q10 tartalom és a GPx (glutation peroxidáz) / GST (glutation $S$-transzferáz) aktivitás változatlan volt, míg a NO (nitrogén-monoxid) és az MDA (malonil-dialdehid) mérsékelten emelkedett, azonban a normál értéktartományon belül.

\begin{tabular}{|c|c|}
\hline Emlős & Tengeri hal \\
\hline Drága & Olcsó \\
\hline Magas olvadási pont & Alacsony olvadási pont \\
\hline Nagy viszkozitású oldat & Alacsony viszkozitású oldat \\
\hline $\begin{array}{c}\text { Nehéz kivonni (Alacsony } \\
\text { elérhetőség) }\end{array}$ & $\begin{array}{l}\text { Könnyen elérhető (Nagy } \\
\text { mennyiség) }\end{array}$ \\
\hline $\begin{array}{c}\text { Szerves oldószerben } \\
\text { oldódik }\end{array}$ & Vízben oldódik \\
\hline $\begin{array}{c}\text { Fertőző betegségek } \\
\text { kockázata }\end{array}$ & $\begin{array}{l}\text { Nincs fertőző betegség } \\
\text { kockázata }\end{array}$ \\
\hline $\begin{array}{l}\text { Alacsony glutaminsav- és } \\
\text { alanin-, magas } \\
\text { prolintartalom }\end{array}$ & $\begin{array}{l}\text { Magas glutaminsav- és } \\
\text { alanin-, alacsony } \\
\text { prolintartalom }\end{array}$ \\
\hline
\end{tabular}

1. Táblázat: Összehasonlító vizsgálatok emlős és tengeri halakból származó kollagén között (Subhan et al. 2015). 
Konklúzió: az MCP-k és a bőrre ható antioxidánsok kombinációja hatékony és biztonságos kiegészítő lehet a bőr tulajdonságainak javítása érdekében az oxidatív károsodás kockázata nélkül (De Luca et al. 2016).

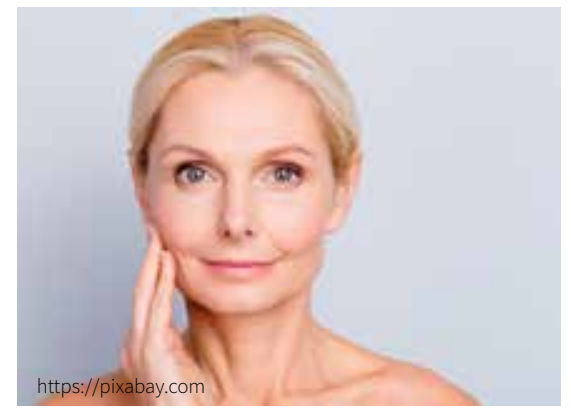

Kollagénkiegészítők hatásai, szerepe, elónye

1.Bôr és a kollagén kapcsolata. A bőr az emberi test legnagyobb méretű szerve, amely számos funkciót tölt be. Fő feladata a fizikai gát szabása a környezeti tényezőknek, mindemellett szenzoros szerepet tölt be.

Bőrünket két fó réteg, az epidermis (felhám) és a dermis (irha) alkotja. A dermis tartalmazza az úgynevezett fibroblasztokat, melyek előállítják az elasztint és a kollagént (Borumand-Sibilla, 2014). A bőr a kor előrehaladtával fiziológiailag megváltozik. Strukturális változásokon megy keresztül, illetve romlás figyelhető meg a neuroszenzoros észlelésekben, a permeabilitásban, a sérülésekből való regenerációs képességében, továbbá fokozódhatnak a bőrbetegségek. A nők bőre a menopauzával járó ösztrogéncsökkenés miatt gyorsabb ütemben esik át funkcionális és strukturális változásokon, mint a férfiaké. Vastagságából folyamatosan veszít, megfigyelhető különösképpen az arcon, nyakon, mellkason és a kezek felületén. Évtizedenként mintegy 6,4\%-kal csökken az epidermális sejtek száma. A bőr természetes vízmegkötő képessége csökken annak eredményeképp, hogy az idős bőr aminosav-összetétele megváltozik, ezáltal csökkenhet a bőr természetes hidratáltsága, tovább csökkentve a bőr vízmegkötő képességét. Az öregedés előrehaladtával automatikusan csökken a fibroblasztok által termelt hialuronsav előállításának mennyisége. A kollagénforgalom is romlik a fibroblasztok kollagénszintézis-lassulása miatt ( $\mathrm{Fa}$ rage et al. 2012).

2. Szemre gyakorolt hatása. A szem külső, erős, fehér része a sclera (ínhártya), mely 80\%-ban kollagén- rostokból felépülő burkot alkot (Coudrillier, 2015).

3. Körmünket, hajunkat egészségesen tartja.

Kollagén bevitele növelheti a körmök szilárdságát, megakadályozva ezzel a törékenységüket. Ösztönözheti a haj és köröm hosszúságának növekedését (Hexsel et al. 2017).

4. Izmok növekedése, regenerációja.

Kollagén peptid pótlásával növelni lehet a zsírmentes testtömeget, valamint az izomrost átmérőjét (Kirmse et al. 2019).

Egy vizsgálat során 27 idős, szarkopén testalkatú férfi napi 15 gramm kollagént szedett, és részt vettek egy testedző programban 12 héten keresztül. A kollagént fogyasztók jelentősen több izmot építettek magukra, mint azok, akik nem szedtek kollagént. Kutatók szerint a kollagén szedése elősegítheti az izomfehérjék, például a kreatin szintézisét, valamint stimulálhatja az izomnövekedést edzés után (Zdzieblik et al. 2015).

5. Porcok, inak, szalagok.

A kollagén a kötőszövetek fő alkotóeleme, beleértve az inakat, szalagokat, bőrt és izmokat (Lodish et al. 2003).

15 gramm zselatin és $50 \mathrm{mg} \mathrm{C}$-vitamin szedése edzések előtt javította az inak teljesítményét azáltal, hogy fokozta a kollagén lerakódását és átalakítását (Shaw et al. 2017). Krónikus bokainstabilitású nők és férfiak 5 gramm kollagént vagy placebót szedtek 6 hónapig. A kollagén csoportba tartozók nagyobb szubjektív stabilitásról számoltak be, és kevesebb bokasérülésük volt a követési időszak alatt (Dressler et al. 2018).

Férfi és nő főiskolai sportolók 24 héten keresztül 10 gramm kollagén-hidrolizátumot szedtek étrendkiegészítőként. A különböző tevékenységek során lényegesen kevesebb ízületi fájdalomról számoltak be. A hatás lényegesen erősebb volt azoknál a résztvevőknél, akiknek korábban már volt térdízületi fájdalmuk (Clark et al. 2008).

6. Erósíti a csontokat.

Osteoarthritis tüneteinek enyhítésében is segítségünkre van a kollagén-peptid pótlás. Hatására jelentős javulás állt be a fájdalomban, merevségben és fizikai funkcióban egyaránt (Lugo et al. 2016).

7. Emésztésre gyakorolt hatása, a bél egészségére gyakorolt hatása.
A kollagén glicintartalma csökkenti a gyomorfekélyek előfordulásának kockázatát, mivel képes megakadályozni a káros gyomorváladékok szekrécióját (Tariq - Al Moutaery, 1997).

A tudomány a kollagénszintézist fontos elemként azonosította a bélfal helyreállításának és gyógyításának folyamatában. Ha a bélfal sérült vagy gyulladt, a bélfal új simaizomsejtek képződésével igyekszik azt meggyógyítani. A tudósok azt találták, hogy a bélben akkor a legnagyobb a kollagéntermelés, amikor simaizomsejtek keletkeznek a gyógyulás során. Így a kollagén kulcsfontosságú eleme a bélfal gyógyításának. A kollagénnel való kiegészítés segíthet a gyomorfal helyreállításában, gyógyulásában (Graham et al. 1987).

Összefüggést találtak a gyulladásos bélbetegségek és a csökkent szérum kollagénszint között (Koutroubakis et al. 2003).

\section{Szív egészsége.}

Egy tanulmány során azoknak az egészséges felnőtteknek, akik 16 gramm kollagént fogyasztottak naponta 6 hónapon keresztül, csökkent az LDL/HDL-koleszterin szintjük. Ezen felül lényegesen alacsonyabb volt az érelmeszesedés kockázatát jelző marker mennyisége a véráramukban a vizsgálat végére (Tomosugi et al. 2017). Egy kisebb kutatás során 15 felnőtt alanyt vizsgáltak, akiknek az enyhe hipertenzióját csökkentette a 4 héten keresztül fogyasztott napi 5,2 gramm kollagén (Saiga-Egusa et al. 2009).

12 héten keresztül napi 2,5 gramm kollagén fogyasztása csökkentette az artériás merevséget (Igase et al. 2018).

\section{Hidrolizált kollagén vs zselatin:}

\section{Mit jelent a hidrolizált kolla-} gén?

A hidrolizált kollagén kis molekulatömegü peptidek csoportja, amelyet enzimatikus úton lehet savas vagy lúgos közegben, meghatározott inkubációs hőmérsékleten előállítani ( $L e-$ ón-López et al. 2019).

Mit jelent a zselatin?

A zselatin kizárólag állati szövetekből, a bőrből, kötőszövetekből és csontokban található kollagén savas vagy lúgos hidrolízise után kioldással, sưrítéssel, majd szárítással nyerhető ki (Csima, 2015). 
Lineáris polipeptid, molekulatömege erősen ingadozó, a nyersanyagtól és az előállítási technológiától függően 10000 és $200000 \mathrm{~g} / \mathrm{mol} \mathrm{közötti.} \mathrm{Az}$ élelmiszeripar segédanyagként alkalmazza az állomány kialakításában. Emellett nagy mennyiségben használ fel zselatint a kozmetikai ipar, a gyógyszeripar és a filmipar is (Csima, 2015).

Fontos megjegyezni, hogy mivel nem használnak enzimeket a zselatin előállításához, a kollagén nincs teljesen lebontva, így azt óriási méretű

fehérjék alkotják. A zselatin hosszú, míg a hidrolizált kollagén rövid láncú aminosavakból áll. Ezért a hidrolizált kollagén sokkal jobb felszívódású, hatékonyabb, mint a zselatin (Csima, 2015; León-López et al. 2019).

A kutatásokban kizárólag előemésztett (hidrolizált) zselatint/kollagént használtak (többnyire italba keverhetô por formájában, vagy már liquid formában). Ezek kollagén peptideket, és nem egész fehérjéket tartalmaznak (Choi et al. 2019).

\section{Kép: Kollagén piac alakulása 2016-2027} (Grand view research, 2020).

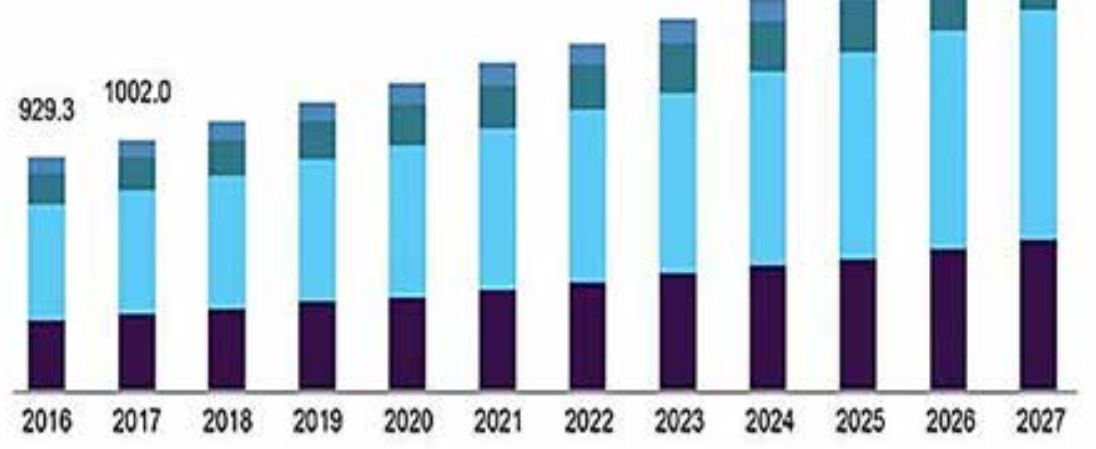

\|étel-ital \| egészségipar घ kozmetikumok \# egyéb

\section{Kollagénfogyasztás alakulása}

2007-2016 között 33\%-os növekedést mutatott a kollagént tartalmazó termékek fogyasztása. Ezen belül a legnagyobb emelkedés a táplálékkiegészítők és a sporttáplálkozás területén mutatkozott (Sarasqueta, 2017).

A kollagéntartalmú kiegészítők iránt nő a kereslet a korkésleltetés és fiatalságmegőrzés igénye miatt. Ugyanis bizonyíthatóan pozitív hatást gyakorol a bőrre, ízületekre és csontokra (Sarasqueta, 2017).

2019-ben a globális kollagénpiaci keresletet 920,1 tonnára becsülték.

Ugyanebben az évben a kollagén piacát a zselatin szegmens uralta, mivel jelentős a termék iránti kereslet élelmiszer-stabilizátorként. A zselatin iránti keresletet az életmód és az étrendi változások befolyásolják a fejlődő országokban, ami a zselatin fogyasztásának növekedéséhez vezet.

A hidrolizált kollagén piacán várható a leggyorsabb növekedés, melyet alátámaszt növekvő felhasználása az egészségügyi szektorban, mint szövetjavító és fogászati alkalmazása (Grand view research, 2020).

\section{Irodalomjegyzék}

1. Bak, M. (2015): Természetes alapú fóliák vizsgálata. Diplomamunka. Miskolci Egyetem, Müszaki Anyagtudományi Kar, Kerámia- ́s Polimermérnöki Intézet, Polimermérnöki Intézet limermérnöki In tézét.

2. Bakilan, F. - Armagan, O. - Ozgen, M. - Tascioglu, F. - Bolluk, O., - Alatas, O. (2016) Effects of Native Type II Collagen Treatment on Knee Osteoarthritis: A Randomized Controlled Trial. The Eurasian journal of medicine. 48. 2. 95-101. DOI: 10.5152/eurasianjmed.2015.15030

3. Bocskai, Z. (2015): A szem biomechanikai viselkedésének modellezése. PhD értekezés. Budapesti Műszaki és Gazdaságtudományi Egyetem Tartószerkezetek Mechanikája

4. Borumand, M. Sibilla, S. (2014): Daily consumption of the collagen supplement Pure gold Collagen ${ }^{\circledast}$ reduces visible signs of aging. Dovepress. 9.1.

5. Choi, F.D. - Sung, C.T. - Juhasz, M. Mesinkovsk, N.A. (2019): Oral Collagen Supplementation: A Systematic Review of Dermatological Applications. Journal of drugs in dermatology. 18. 9-16.

6. Christov, C. Z. (2016): Species Identification of Bovine, Ovine and Porcine Type Collagen; Comparing Peptide Mass Fingerprinting and LC-Based Proteomics Methods. From: ting and LC-Based Proteomics Methods. From: https://wwW.mdpi.com/1422-00

7. Clark, K. L. - Sebastianelli, W. - Flechsenhar, K. R. - Aukermann, D. F. - Meza, F. Millard, R. L. - Deitch, J. R. - Sherbondy, P. S - Albert, A. (2008): 24-Week study on the use of collagen hydrolysate as a dietary supplement in athletes with activity-related joint pain. Current medical rese Current medical research and opinion. 24.5 .

8. Coudrillier, B. - Pijanka, J. - Jefferys, J. - Sorensen, T. - Quigley, H. A. - Boote, C. Nguyen, T. D. (2015): Collagen structure and mechanical properties of the human sclera: analysis for the effects of age. Journal of biomechanical engineering. 137. 4. 041006. DOI: 10.1115/1.4029430

9. Csima, Gy. (2015): Zselatin alapú édesipari termék reológiájának jellemzése. Doktori disszertáció. Budapesti Corvinus Egyetem. 10-12. o. DOI: 14267/phd.2015035.

10. De Luca, C. - Mikhal'chik, E. V. - Suprun, M. V. - Papacharalambous, M. - Truhanov, A. I - Korkina, L (2016): Skin Antiageing A. I. Korkina, L. G. (2016): Skin Antiageing plementation with Marine Collagen Peptides an Plant-Derived Antioxidants: A Single-Blin Case-Control Clinical Study. Oxidative medicine and cellular longevity, 2016. 1-14. DOI: $10.1155 / 2016 / 4389410$

11. Dressler, P. - Gehring, D. - Zdzieblik, D. - Oesser, S. - Gollhofer, A. - König, D. (2018): Improvement of Functional Ankle Properties Following Supplementation with Specific Collagen Peptides in Athletes with Chronic Ankle lagen Peptides in Athletes with Chronic Ankle Instability. Journal of sports scien
ne. 1. 2. 298-304. PMID: 29769831

ne. 1. 2. 298-304. PMID: 29769831
12. Graham, M. F. - Drucker, D. E. - Diegelmann, R. F. - Elson, C. O. (1987): Collagen synthesis by human intestinal smooth muscle cells in culture. Gastroenterology. 92. 2. 400-405. DOI: 10.1016/0016-5085(87)90134-x

13. Hexsel, D. - Zague, V. - Schunck, M. Siega, C. - Camozzato, F. O. - Oesser, S. (2017): Oral supplementation with specific bioactive collagen peptides improves nail growth and reduces symptoms of brittle nails. Journal of cosmetic dermatology. 16. 4. 520-526. DOI: 10.1111/jocd.12393

14. Igase, M. - Kohara, K. - Okada, Y. Ochi, M. - Igase, K. - Inoue, N. - Kutsuna, T. Miura, H. - Ohyagi, Y. (2018): A double-blind, placebo-controlled, randomised clinical study of the effect of pork collagen peptide supplementation on atherosclerosis in healthy older individuals. Bioscience, biotechnology, and biochemistry. 82. 5. 893-895. DOI: 10.1080/09168451.2018.1434406

15. Kirmse, M. - Oertzen-Hagemann, $V$. - Marées, M. - Bloch, W. - Platen, P. (2019): Prolonged Collagen Peptide Supplementation and Resistance Exercise Trainin tation and Resistance Exercise Training
Affects Body Composition in RecreatioAffects Body Composition in Recreatio-
nally Active Men. From: https://pubmed. nally Active Men. From: https://pubmed. nu11051154

16. Koutroubakis, I. E. - Petinaki, E. - Dimoulios, P. - Vardas, E. - Roussomoustakaki, M. - Maniatis, A. N. - Kouroumalis, E. A. (2003): Serum laminin and collagen IV in inflammato- ry bowel disease. Journal of clinical pathology. 56. 11. 817-820. DOI: 10.1136/jcp.56.11.817 17. León-López, A. - Morales-Peñaloza, A. - Martínez-Juárez, V. M. - Vargas-Torres, A. - Zeugolis, D. I. - Aguirre-Álvarez, G. (2019): A. Zle Applications. Molecules. 24.22. 4031. DOl: $10.3390 /$ molecules 24224031

18. Lodish, H. - Berk, A. - Matsudaira, P. - Kaiser, C.A. - Krieger, M. - Scott, M.P. - Zipursky, L. - Darnell, J. (2003): Molecular Cell Biology. 5th edition. W. H. Freeman, New York, 15. p.

19. Lugo, J. P. - Saiyed, Z. M. - Lane, N. $E$ (2016): Efficacy and tolerability of an undenatured type II collagen supplement in modulating knee osteoarthritis symptoms: a multicenter randomized, double-blind, placebo-controlled study. From: https://www.ncbi. nlm.nih.gov/pmc/articles/PMC4731911/ DOI: 10.1186/s12937-016-

20. Miranda, A. F. - Kenneth, W. M. - Peter, E.- Howard, I. M. (2012): Characteristics of the Aging Skin: Critical Reviews. Wound Healing Society. 7-9. DOI: 0.1089/wound.2011.0356

21. Paul, C. - Leser, S. - Oesser, S. (2019): Significant Amounts of Functional Collagen Peptides Can Be Incorporated in the Diet While maintaining Indispensable Amino Acid Balance. From: https://pubmed.ncbi.nlm.nih. gov/31096622/ DOI: 10.3390/nu11051079 22. Saiga-Egusa, A. - Iwai, K. - Hayakawa,
T. - Takahata, Y. - Morimatsu, F. (2009): Antihypertensive effects and endothelial progenitor cell activation by intake of chicken collagen hydrolysate in pre- and mild-hypertension. Bioscience, biotechnology, and biochemistry. 73. 2. 422-424. DOI: 10.1271/bbb. 80189

23. Sarasqueta, J. (2017): Trends in Collagen. From: https://www.gelita.com/sites/ default/files/documents/2017-05/InnovaMarketInsights Gelita_Collagen Presentation.pdf

24. Shaw, G. - Lee-Barthel, A. - Ross, M. L. - Wang, B. - Baar, K. (2017): Vitamin C-enriched gelatin supplementation before intermittent activity augments collagen synthesis. The American journal of clinical nutrition. 105. 1. 136-143. DOI: 10.3945/ajcn.116.138594

25. Silva, T. H. - Moreira-Silva, J.

Marques, A. L. - Domingues, A. - Bayon, Y. Reis, R. L. (2014): Marine origin collagens and its potential applications. Marine drugs. 12. 12. 5881-5901. DOI: $10.3390 / m d 12125881$ 26. Song, H. - Zhang, S. - Zhang, L. - Li, B. (2017): Effect of Orally Administered Collagen Peptides from Bovine Bone on Skin Aging in Chronologically Aged Mice. Nutrients. 9. 11. 1209. DOI: 10.3390/nu9111209

27. Sripriya, R. - Kumar R. (2015): A Novel Enzymatic Method for Preparation and Characterization of Collagen Film from Swim Bladder of Fish Rohu (Labeo rohita). Food and Nutrition Sciences. 6. 1468-1478. DOI: 10.4236/fns.2015.615151

28. Subhan, F. - Ikram, M. - Shehzad, A - Ghafoor, A. (2015): Marine Collagen: An Emerging Player in Biomedical applications. Journal of food science and technology, 52.8. 4703-4707. DOI: 10.1007/s13197-014-1652-8

29. Sylvie, Ricard-Blum. (2011): The collagen family. Cold Spring Harbor Perspectives in Biology. 1. DOl:10.1101/cshperspect. a0049780130-8

30. Tariq, M. - Al Moutaery, A. R. (1997): Studies on the antisecretory, gastric anti-ulcer and cytoprotective properties of glycine. Research communications in molecular pathology and pharmacology. 97. 2. 185-198. PMID: 9344231

31. Tomosugi, N. - Yamamoto, S. Takeuchi, M. - Yonekura, H. - Ishigaki, Y. - NuMatsuda, S. - Sakai, Y. (2017): Effect of Collagen Tripeptide on Atherosclerosis in Healthy Humans. Journal of atherosclerosis and thrombosis. 24. 5. 530-538. DOI: 10.5551/ jat.36293

32. Tung, P. S. - Domenicucci, C. - Wasi, S. - Sodek, J. (1985): Specific immunohistochemical localization of osteonectin and collagen types I and III in fetal and adult porcine dental tissues. Journal of Histochemistry \& Cytochemistry. 33. 6. 531-540. DOI: $10.1177 / 33.6 .3889139$

33. Zdzieblik, D. - Oesser, S. - Baumstark, M. W. - Gollhofer, A. - König, D. (2015): Collagen peptide supplementation in combination with resistance training improves body composition and increases muscle strength in elderly sarcopenic men: a randomised controlled trial. The British journal of nutrition. 114. 8. 1237-1245. DOl: 10.1017/ nutrition. 114. 8. 1237-1245. DOI: 10.1017/
S0007114515002810 